\title{
| Licitude da cobrança de tarifa mínima para manutenção de serviços públicos de fornecimento de água e de coleta de esgoto
}

\author{
Thiago Marrara*
}

\section{Parecer}

\section{Do estudo solicitado e sua contextualização}

O estudo a seguir baseia-se na Ordem de Serviço de 13 de novembro de 2017, pela qual a Ares-PCJ (Agência Reguladora dos Serviços de Saneamento das Bacias dos Rios Piracicaba, Capivari e Jundiaí, consórcio intermunicipal com personalidade jurídica de direito público) solicita subsídios legais, doutrinários e jurisprudenciais à resolução das duas indagações a seguir:

1 - Com base na legislação de saneamento brasileira e nos preceitos de direito administrativo é lícito instituir a cobrança de tarifa mínima (de que é espécie a tarifa básica operacional - TBO) para manutenção dos serviços de água e esgoto?

* Professor associado de direito administrativo da Universidade de São Paulo (USP) na Faculdade de Direito de Ribeirão Preto (FDRP). Livre-docente (USP). Doutor pela Universidade de Munique (LMU). Editor da Revista Digital de Direito Administrativo (RDDA). Advogado-consultor inscrito na OAB/SP sob o no 280.490 . 
2 - As tarifas dos serviços de água e esgoto estão vinculadas à legislação consumerista, devendo cobrar do usuário somente o serviço efetivamente usufruído ou tal preceito do Código de Defesa do Consumidor pode ser afastado?

A agência reguladora consulente, Ares-PCJ, constituída no modelo de consórcio público com personalidade de direito público interno e responsável pela regulação de serviços de saneamento básico em dezenas de municípios do estado de São Paulo, esclarece que as tarifas mínimas configuram preços públicos cobrados das unidades usuárias com base ora em um volume mínimo de consumo dos serviços de água/esgoto, ora nos valores fixos para manutenção da infraestrutura em pleno e adequado funcionamento (caso em que se utiliza a expressão "tarifa operacional básica"), somada ou não à cobrança por um mínimo de consumo.

Apesar de suas diferentes formas, no geral, a cobrança das tarifas mínimas se mostra fundamental para a cobertura de custos fixos de capital e operacionais, ou seja, valores que não variam no curto prazo a despeito de variações de demanda e servem à realização de investimentos essenciais para promover a universalização, a integralidade, a eficiência e a sustentabilidade econômica (art. 2º ${ }^{\circ}$ incisos I, II e VII, da Lei Federal nํㅜ 11.445/2007), bem como à manutenção da operação da rede e da disponibilidade do serviço público à sociedade.

Apesar de essas tarifas exercerem uma função objetiva e alinhada à legislação setorial, a consulente revela que os órgãos de controle, como o Ministério Público e a Defensoria Pública do Estado de São Paulo, têm questionado a legalidade das cobranças mínimas e levantado outros questionamentos sobre a estruturação tarifária para serviços de saneamento básico, de sorte a colocar em risco sua autonomia regulatória e, em última instância, comprometer a eficiência das atividades de fornecimento de água e coleta de esgoto.

A partir dos fatos narrados, para se verificar a licitude da referida tarifa mínima, de que é espécie a chamada "tarifa básica operacional", e para se atestar se e em que medida a autonomia da agência reguladora pode ser limitada por órgãos de controle externo, sobretudo com apoio em normas de defesa do consumidor, o presente estudo divide-se em três partes:

- A primeira trata de aspectos gerais acerca da remuneração de serviços públicos, explicando os modelos existentes no Brasil, os critérios que necessitam ser considerados na definição do modelo remuneratório e os elementos de custos que permeiam a chamada "estruturação 
tarifária", oferecendo-se assim a base teórica para a compreensão dos serviços de saneamento e suas tarifas;

- A segunda parte ingressa no exame da legislação setorial para delinear o regime jurídico das tarifas de saneamento básico, dando especial destaque para os serviços públicos de água e esgoto e para as normas que cuidam da estruturação tarifária. Nessa parte se revela a opção preferida pelo legislador quanto à tarifação de água e de esgoto e se destacam as normas autorizativas da cobrança de tarifas mínimas para garantir o serviço público adequado; e

- A terceira e última parte cuida da relação entre normas regulatórias e normas de defesa do usuário e dos consumidores. Nela se apontam as razões pelas quais normas técnicas acerca da estruturação tarifária construídas por agências reguladoras prevalecem sobre normas básicas previstas em diplomas genéricos de defesa do consumidor, como o CDC. Em complemento, sistematiza-se a jurisprudência específica acerca da legalidade de cobrança de tarifas básicas de água e esgoto no Brasil, conferindo-se especial atenção às decisões do Superior Tribunal de Justiça.

\section{Tarifação de serviços públicos: aspectos teóricos gerais}

\subsection{Remuneração de serviços públicos}

Toda e qualquer tarefa estatal gera custos elevados. E não poderia ser diferente com os serviços públicos, atividades cuja extensão, complexidade e modo de funcionamento os torna frequentemente mais dispendiosos que ações corriqueiras de mercado. Não é à toa que, embora alguns serviços estejam por vezes abertos à livre-iniciativa (serviços impróprios ou não monopolizados) ou, quando monopolizados, o Estado busque privatizá-los por meio de técnicas de delegação, poucos agentes econômicos mostram-se capazes de assumi-los.

Em termos financeiros e igualmente políticos, a questão central que se coloca de modo constante aos titulares estatais dos serviços públicos é a seguinte: quem assumirá seus elevados custos? Em certas ocasiões, o próprio legislador responde à pergunta com a escolha de um modelo de custeio. Em outras ocasiões, ele apenas oferece, por meio do direito positivo, alternativas de respostas, cada qual com impactos e implicações distintas sobre os 
mais diversos agentes envolvidos. Em hipóteses como essa, deixa-se margem de escolha para a Administração desenvolver o modelo de geração das receitas que sustentarão o serviço.

No âmbito dos chamados serviços econômicos, comerciais ou industriais, é usual que o ordenamento preveja o custeio dos serviços direta e exclusivamente pelos usuários, pessoas físicas ou jurídicas. Predominam as receitas tarifárias, como se vislumbra nos setores de energia, telefonia, assim como de água e de esgoto. Em serviços dessa natureza, não há previsões genéricas e absolutas de gratuidade, senão meras e ocasionais determinações infraconstitucionais de tarifas sociais ou de gratuidade restrita a grupos vulneráveis específicos.

Já no campo dos denominados serviços públicos sociais, a estipulação geral de gratuidade é mais comum, como se vislumbra na regra constitucional que veda o pagamento de ensino em estabelecimentos públicos (art. 206, IV da CF) ou na regra legal que torna gratuitos os serviços de saúde no SUS (art. 43 da Lei no 8.080/1990). A opção da gratuidade comumente encontrada nos serviços sociais desloca o custeio que seria assumido pelo usuário final para outros atores, em geral para a população como pagadora de impostos. Utiliza-se um modelo de receitas não tarifárias.

Em qualquer situação, a despeito da categoria do serviço público, opção por uma ou outra forma de remuneração resta sempre condicionada pela natureza indivisível (uti universi) ou divisível (uti singuli) da prestação. Em poucas palavras, os indivisíveis, como os de limpeza urbana e drenagem de águas pluviais, não aceitam taxa, nem tarifa, dada a impossibilidade de se verificar o consumo ou o potencial de consumo de cada usuário. Daí a necessidade de que sejam custeados por meio de impostos e, eventualmente, por meio de receitas alternativas geradas no âmbito de contratos de concessão (receitas não tarifárias) - salvo quando o legislador, contrariando toda a lógica, previr cobranças individualizadas para sua manutenção, como a esdrúxula contribuição de iluminação pública, prevista no art. 149-A da Constituição da República, incluído pela Emenda Constitucional no 39/2002. ${ }^{1}$

Em contraste, a modelagem de custeio dos serviços divisíveis, como distribuição de água e de coleta de esgoto, é muito flexível. Além do uso de

1 Art. 149-A Os Municípios e o Distrito Federal poderão instituir contribuição, na forma das respectivas leis, para o custeio do serviço de iluminação pública, observado o disposto no art. 150, I e III. Parágrafo único. É facultada a cobrança da contribuição a que se refere o caput, na fatura de consumo de energia elétrica. 
impostos, de receitas alternativas (autorizadas em contratos de concessão ou de permissão) e de subsídios cruzados provenientes de outros usuários (conforme previsão em certas leis), é possível cobrar taxa ou tarifa do usuário final para cobrir total ou parcialmente os custos de estruturação, manutenção e prestação do serviço público, ou seja, todos os custos fixos e variáveis, de capital ou de operação. A margem de discricionariedade do titular do serviço para combinar inúmeras técnicas de custeio variará de acordo com as opções do legislador, frequentemente consignadas na legislação setorial, como se demonstrará ao longo da análise do setor de água e de esgoto.

Por ora cumpre simplesmente registrar que, em termos gerais, os altos e variados custos que um serviço público adequado gera - tanto para sua manutenção e operação quotidiana quanto para sua universalização e atualização tecnológica - podem ser sustentados por diferentes fontes e conforme modelos que se diferenciam pela natureza do serviço e pelas amarras dadas pelo ordenamento. Grosso modo, no Brasil frequentemente se identificam três modelos:

- O do "serviço público remunerado integralmente pelos usuários". Aqui, a taxa ou tarifa cobrada do usuário abarca todos os custos internos e externos, fixos e variáveis, de operação e de capital. Para tanto, é preciso que: i) o serviço se caracterize pela divisibilidade; ii) a taxa esteja prevista em lei ou, alternativamente, a tarifa conste de contrato de delegação; iii) a cobrança retrate os custos para a prestação do serviço adequado; e iv) a cobrança não seja abusiva, excessiva ou exageradamente elevada (princípio da modicidade). Esse é o modelo prioritário para serviços de água e esgoto, como se demonstrará oportunamente.

- O do "serviço público remunerado parcialmente pelos usuários". Nessa hipótese, a remuneração do usuário para custear o serviço será deficitária, exigindo receitas não tarifárias como o pagamento de subsídios previstos em contrato (art. 17, caput da Lei no 8.987/1995), uma contraprestação do parceiro público, caso se trate de PPP patrocinada (art. 2oㅡ $\S^{1} 1^{\circ}$ da Lei $n^{\circ}$ 11.079/2004), e/ou a geração de receitas alternativas (art. 11 da Lei no 8.987/1995). Como esse modelo pressupõe que o serviço se caracterize pela divisibilidade, ele é perfeitamente aplicável também nos setores de água e de esgoto.

- E o modelo do "serviço não custeado pelo usuário final", que se aplica em duas situações. A primeira se refere aos serviços uti universi, cuja cobertura financeira ocorre, via de regra, por impostos ou 
receitas alternativas, salvo no caso da iluminação pública, que dispõe de contribuição específica. A segunda situação se refere a serviços divisíveis, mas a que o ordenamento expressamente atribui gratuidade, ou seja, proíbe a cobrança individualizada de taxas ou tarifas por norma constitucional ou infraconstitucional. É igualmente concebível que referida gratuidade venha determinada por decisão administrativa. Em qualquer hipótese, fato é que a gratuidade não faz desaparecer os custos dos serviços. Ela simplesmente altera a fonte de custeio. O serviço terá que ser suportado ou pela coletividade, ou por receitas alternativas, ou por subsídios cruzados de outro grupo de usuários, ou seja, por receitas não tarifárias.

\subsection{Natureza da tarifa de serviços públicos}

Os modelos baseados na remuneração dos serviços pelo usuário - como o empregado no campo dos serviços públicos de água e de esgoto por força da legislação setorial a ser oportunamente examinada - sustentam-se na cobrança de taxa ou de tarifa (preço). Ambos os institutos desempenham função análoga, embora com sensível diferença no tocante ao regime jurídico.

A "taxa" é espécie tributária cabível apenas para a prestação direta e submetida à legalidade forte (previsão estrita de alíquota, base de cálculo, fato gerador e outros elementos em lei em sentido formal). A seu turno, a "tarifa" configura um preço regulado, instituído na delegação do serviço e inserido num regime mais flexível que excepciona o direito tributário por força de norma constitucional expressa. A esse respeito, o STF esclareceu na Súmula 545 que "preços públicos e taxas não se confundem, porque estas, diferentemente, daqueles, são compulsórias e têm sua cobrança condicionada à prévia autorização orçamentária, em relação à lei que as instituiu".

A diferença fundamental entre os regimes da taxa e da tarifa se ancora na Constituição, cujo art. 175 prevê a possibilidade de que os serviços públicos sejam executados diretamente pelo seu titular estatal ou indiretamente por delegatário (i.e., concessionário ou permissionário) escolhido por meio de processo licitatório. Além disso, referido dispositivo cria o sistema de remuneração por tarifa para a execução indireta, submetendo-o a reserva legal ao exigir que lei disponha, entre outras coisas, sobre a política tarifária (art. 175, parágrafo único, III). 
Ao tratar das formas possíveis de execução das atividades em questão, Alexandre Santos de Aragão afirma que o artigo 175 da Constituição abre uma exceção ao regime tributário previsto pela Constituição para os serviços públicos que seriam remunerados por taxa, de forma que, sempre que o serviço público, compulsório ou não, tiver sido delegado, a sua remuneração se dará por tarifa. ${ }^{2}$ Isso significa, como reforça Maria Sylvia Zanella Di Pietro, que a tarifa será o único instituto cabível para a cobrança direta do usuário quando o serviço for prestado por meio de concessão ou permissão. ${ }^{3}$ E não poderia ser diferente. Impor a instituição de taxa para serviços delegados inviabilizaria sua execução, já que a taxa é incapaz de assegurar, pela rigidez de seu regime, o respeito ao direito de equilíbrio econômico-financeiro atribuído pela legislação ao prestador. ${ }^{4}$

Não há outra conclusão possível a partir do exame da disciplina infraconstitucional do assunto. Em respeito à reserva legal prevista na Constituição, o Congresso Nacional editou a Lei Geral de Concessões e Permissões de Serviços Públicos (Lei no 8.987/1995), assim como leis especiais para cada setor, como a Lei de Saneamento Básico (Lei no 11.445/2007), no intuito de explicar o emprego da tarifa na execução delegada dos serviços públicos.

Na Lei Geral de Concessões, diploma nuclear para a compreensão dessa matéria, dedicou-se todo o capítulo IV ao tema "da política tarifária". Seus dispositivos gerais, entre outras coisas, preveem que: i) a tarifa será fixada de acordo com as normas da licitação e do contrato, observando-se a proposta do licitante vencedor; ii) a tarifa será preservada em seu valor por revisão ou reajuste no intuito de garantir o equilíbrio econômico-financeiro do contrato de delegação do serviço; iii) sua cobrança poderá ser condicionada a serviço alternativo e gratuito ao usuário somente quando houver previsão em lei para tanto; iv) o valor gerado pelas tarifas para custeio do serviço poderá ser complementado por "fontes provenientes de receitas alternativas, complementares, acessórias ou de projetos associados, com ou sem exclusividade [...]"; e v) a tarifa pode ser diferenciada em razão de características técnicas ou dos custos específicos provenientes do atendimento aos distintos segmentos de usuários.

2 ARAGÃO, Alexandre Santos de. Direito dos serviços públicos. 2. ed. Rio de Janeiro: Forense, 2008.

3 DI PIETRO, Maria Sylvia Zanella. Parcerias na administração pública: concessão, permissão, franquia, terceirização, parceria público-privada e outras formas. 6. ed. São Paulo: Atlas, 2008. p. 384 .

4 Ibid., p. 385. 
A partir daí se evidencia, conforme preleciona Fernando Vernalha Guimarães, que a tarifa consiste num preço ou contraprestação que os usuários praticam em face da utilização do serviço e da infraestrutura pública disponibilizada pelo delegatário. ${ }^{5}$ Ela deve ser compreendida, por conseguinte, no entrecruzamento de três relações jurídicas coordenadas entre si: a que se estabelece entre usuário (e não usuários) e o poder concedente, quando da concepção e idealização do serviço público e de sua tarifação; a travada entre o delegatário e o titular do serviço, bem como a existente entre concessionário e usuário, assumindo a tarifa, aqui, o papel de contraprestação arcada pelo usuário como contrapartida à prestação do serviço adequado. ${ }^{6}$

A essa pluralidade de relações se deve adicionar uma quarta, a saber: a que envolve o prestador, delegado ou não, e o regulador, como entidade pública dotada de autonomia para encontrar as melhores soluções técnicas com o objetivo de viabilizar um serviço adequado e capaz de satisfazer os direitos e interesses juridicamente tutelados de todos os atores envolvidos. Somente com a consciência dessa multiplicidade de relações, inclusive com o regulador, é que se poderá compreender a tarefa de estruturação tarifária, inclusive no setor de saneamento.

\subsection{Estrutura ou composição tarifária}

A complexidade da prestação de serviços públicos e a pluralidade de atores e relações jurídicas que a caracteriza revelam que a tarifa não pode ser estruturada, examinada nem questionada de perspectivas reducionistas, microscópicas ou de curto prazo. Da mesma forma que sua precificação não poderia ser realizada com a mera consideração dos interesses do prestador, ela jamais poderia ser calculada a partir da consideração exclusiva da quantidade ou volume de serviço diretamente consumido por um ou outro usuário final (mera fruição individualizada).

A estruturação tarifária como método de definição das tarifas cobradas dos mais diferentes grupos de usuários necessita levar em conta uma série de outros fatores que se extraem do plexo mencionado de relações jurídicas.

5 GUIMARÃES, Fernando Vernalha. Concessão de serviço público. São Paulo: Saraiva, 2012. p. 178.

6 Ibid. 
Entre tantos fatores, cabe destacar: a modelagem adotada na fase interna e vinculante do processo licitatório; a garantia do equilíbrio econômico-financeiro ao prestador; a existência ou não de regras de gratuidade para grupos de consumidores; o dever de prestação do serviço adequado para as gerações presentes e futuras; a consequente necessidade de expansão de rede para atendimento a usuários em pontos territoriais diversos e de manutenção da infraestrutura existente em bom funcionamento; a previsão de subsídios; o pagamento de taxas regulatórias pelo prestador etc.

Em outras palavras, a precificação abarca necessariamente fatores de custo externos e inerentes ao serviço. Os fatores internos se referem a custos exclusivos do serviço em si, incluindo os custos fixos e variáveis de produção (como os de construção e expansão de rede), os de operação (como de energia elétrica e transporte), os de manutenção (como os de verificação de segurança e de avaliação de qualidade), bem como os custos da efetiva oferta ao usuário final (e.g., volume consumido do bem ou quantidade de serviços solicitados). Já os fatores externos dizem respeito a custos não derivados das operações do serviço em si, mas relacionados com sua existência, como os de retorno esperado do executor, de cobertura de projetos elaborados no PMI, de subsídios cruzados entre os usuários atuais ou de diferentes gerações etc. Alguns desses custos externos são naturais em delegações de serviços, como os de remuneração do prestador, outros são eventuais e dependem de previsão, como os de cobertura de projetos escolhidos em PMI ou o pagamento de subsídios cruzados para sustentar usuários vulneráveis.

A partir dos vários fatores que cada legislação setorial entende cabível e que o regulador mensura na prática, concebem-se três tipos básicos de tarifa: a superavitária, a deficitária e a justa. Além disso, mesmo em serviços divisíveis e tarifados, é igualmente possível a definição de gratuidade limitada a certos grupos de usuários (por força de decisão constitucional, legal ou administrativa), ou seja, a isenção seletiva e justificada de tarifa.

A ideia de tarifa superavitária e deficitária há que ser pensada sempre a partir da "tarifa justa", aqui entendida como o valor pago pelo usuário para cobrir com exatidão todos os custos internos e externos naturais da delegação, como a remuneração do prestador. Diferentemente, entende-se como superavitária a tarifa que gera recursos excedentes aos necessários para cobrir os custos internos e externos naturais. Como ela comporta um excedente que geralmente serve para cobrir custos externos eventuais, como os subsídios cruzados em favor de usuários em situação de vulnerabilidade, a exemplo do que se vislumbra no setor de transporte urbano (art. 9o, §5o da 
Lei no 12.587/2012 ou Lei de Mobilidade Urbana) ou custos de construção de infraestruturas para usuários futuros, sua previsão geralmente necessita de previsão legal.

A tarifa deficitária, a seu turno, representa um preço incapaz de suportar os custos internos e os custos externos naturais (geralmente, o valor de produção, manutenção, operação e prestação do serviço em si somado à remuneração do prestador). Por isso, tanto a tarifa deficitária quanto as hipóteses de gratuidade a certos grupos de usuários geram o mesmo efeito econômico. A parcela não paga pelos usuários beneficiados acarreta uma transferência dos custos para outros agentes. $\mathrm{O}$ custo não desaparece pelo fato de o usuário ter deixado de cobri-lo em virtude de desconto tarifário ou da gratuidade; ele simplesmente é deslocado para outro agente social ou econômico.

Considerando a relação complexa e as amarras que a delegação de serviços envolve no direito brasileiro, esses custos descobertos por conta da tarifa deficitária ou da gratuidade somente podem ser transferidos para os seguintes atores: i) a coletividade, que os assume por meio de seus impostos convertidos em subsídios ou contraprestações ao prestador a depender da modelagem contratual (concessão comum ou PPP); ii) os outros usuários, desde que a legislação autorize subsídios cruzados baseados em tarifas superavitárias ou iii) outros agentes econômicos, caso o contrato preveja receitas alternativas e elas se mostrem possíveis na prática diante das características dos serviços - o que, aliás, dificilmente ocorre nos serviços de água e esgoto.

Reitere-se, pois, que sempre que o usuário final deixar de custear qualquer parcela dos custos de produção, operação, manutenção e oferta de um serviço - nisso se incluindo, portanto, os de sustentação da infraestrutura disponível -, o valor faltante terá que ser compensado por algum outro agente. E caso essa compensação não ocorra, o serviço se tornará insustentável financeiramente e, por consequência, inadequado ou, em pior situação, inexequível, deixando de ser prestada a parcela dos usuários.

Dessa maneira, conquanto possa haver serviço gratuito ou parcelas deficitárias a um ou outro grupo de usuários, não há serviço sem custo! Serviço gratuito ou serviço a preço deficitário é sinônimo de serviço sustentado por outras fontes que não a de pagamento pelo usuário com base exclusiva no benefício recebido ou colocado à disposição. Daí se conclui que, em grande parte dos cenários, ao se impossibilitar a cobrança de uma tarifa justa, causa-se sempre um impacto nocivo: ou se onera mais ainda a sociedade, ou se torna o 
serviço precário em desfavor do próprio usuário final. Não são outras, senão essas, as consequências causadas por ocasionais ações levianas de órgãos de controle contra normas de tarifação em setores regulados.

\subsection{Custos fixos e tarifação mínima}

Os fatores ou custos internos envolvem os gastos para a existência, o funcionamento e a disponibilização do serviço ao usuário final. Em todas essas etapas, os custos se sujeitam a diversas classificações. Há custos de capital, necessários a investimentos, e custos de operação, necessários ao funcionamento do que já existe. Além disso - e o que mais importa a este estudo -, há custos variáveis e fixos, ou seja, custos que respectivamente variam ou não no curto prazo conforme a demanda efetiva das unidades usuárias conectadas à rede.

No serviço de abastecimento de água (que envolve tarefas de captação, tratamento e distribuição) e de coleta de esgoto (que abrange atividades de afastamento, tratamento e disposição final), por exemplo, independentemente do consumo maior ou menor de cada domicílio em certo mês, o prestador arca com custos constantes de remuneração de um corpo de empregados, custos com medição individualizada de consumo (leitura) e emissão de faturas, bem como de eventual aluguel de suas instalações, impostos sobre a propriedade, valores para pagamentos de softwares, atendimento às metas de investimentos constantes do Plano Municipal de Saneamento, manutenção de equipamentos e da rede de infraestrutura, amortização de investimentos na construção de infraestrutura, atendimento telefônico ao usuário etc.

Esses e outros elementos de despesa configuram custos fixos, pois, a despeito das variações pontuais do consumo de água e de coleta de esgoto, eles permanecem constantes por algum tempo. Para que o serviço funcione permanentemente e de modo adequado, custos dessa natureza se mostram inevitáveis. Eles existirão em igual medida a despeito das variações de consumo ou do fato de algumas dezenas de famílias, por exemplo, em razão de viagem nas férias de final de ano, não terem utilizado água em seus domicílios, nem gerado esgoto expressivo. É por isso que se faz necessária uma tarifa mínima, por exemplo, como forma de tarifa operacional básica, com ou sem pagamento de consumo mínimo.

Em tese específica sobre os serviços de saneamento básico, Valmir de Albuquerque Pedrosa confirma a diversidade de custos que os caracteriza 
e, ao fazê-lo, ressalta os diversos custos fixos que as tarifas cobradas pelos prestadores desse setor espelham, ou seja, custos que não variam no curto prazo com relação à quantidade de água ou esgoto, como os de manutenção das máquinas e reposição de equipamentos obsoletos. ${ }^{7}$ Aroldo João Costa caminha no mesmo sentido ao explicar que, por definição, os custos fixos são aqueles que independem da quantidade produzida, incluindo-se nessa categoria, entre outros, os custos de área e instalações necessários aos serviços de saneamento básico. ${ }^{8}$

Diferentemente dos fixos, os custos variáveis aumentam ou diminuem conforme a demanda concreta e atual do serviço. Exemplos disso são os custos com produtos químicos para tratamento da água ou do esgoto, bem como os custos de energia do maquinário necessário a tanto, como o funcionamento de bombas. ${ }^{9}$ Voltando-se ao exemplo dado, o fato de dezenas de famílias deixarem de consumir água e gerar esgoto por conta das viagens durante o período de férias de final de ano ocasionará uma redução proporcional desses custos variáveis, mas os custos fixos, como dito, permanecerão idênticos.

A partir dessa simples classificação econômica entre custos fixos e custos variáveis, fica bastante evidente que o custo total que um usuário de serviço público acarreta ao Estado e, por consequência, à coletividade não se mede somente a partir da quantidade consumida pela unidade usuária. $\mathrm{O}$ custo do serviço de água e de esgoto, portanto, não se reduz ao mero volume de água fornecido e de esgoto coletado. Em todo serviço público, assim como ocorre nas atividades econômicas, existem custos invariáveis, cuja inevitabilidade está atrelada à necessidade de se garantir que o serviço possa ser prestado com qualidade assim que o usuário desejar. Exatamente por isso, enquanto uma pessoa física ou jurídica estiver vinculada ao prestador na qualidade de usuário e não solicitar o desligamento da rede, esses custos fixos deverão ser por ela absorvidos sob pena de se transferi-los ilegitimamente à sociedade ou a outros usuários.

7 PEDROSA, Valmir de Albuquerque. Tarifas nas empresas de saneamento. Tese (doutorado em engenharia de recursos hídricos e saneamento ambiental) - Universidade Federal do Rio Grande do Sul, Porto Alegre, 2001. p. 80. Disponível em: <www.ctec.ufal.br/professor/vap/ TeseValmir.pdf>. Acesso em: 20 nov. 2017.

8 COSTA, Aroldo João. Metodologia para análise de tarifas de sistemas de abastecimento de água SAA com base nos custos de implantação e operação do sistema. Dissertação (mestrado em engenharia ambiental) - Universidade Federal de Santa Catarina, Florianópolis, 2003. p.39-40. Disponívelem:<https://repositorio.ufsc.br/bitstream/handle/123456789/85453/202872. pdf?sequence=1>. Acesso em: 20 nov. 2017.

9 Valmir de Albuquerque Pedrosa, Tarifas nas empresas de saneamento, op. cit., p. 80. 
É essa lógica que torna lícita e legítima perante a sociedade a cobrança de tarifa mínima para manutenção de redes - em alguns locais, denominada de tarifa operacional básica. Essa cobrança é devida por todos os usuários ativos, conectados à rede de serviço, ainda que façam maior ou menor uso dele em um ou outro período. E isso se deve ao fato de que o valor da tarifa mínima não se destina a cobrir os custos variáveis, mas sim os custos fixos que o serviço acarreta e que, não fossem assumidos pelo usuário, onerariam indevidamente o patrimônio de outrem. Como técnica de justa divisão dos custos, a tarifa mínima incidirá sempre na razão do custo fixo total pelo número de usuários conectados à rede.

Essa técnica de cobrança, destinada a garantir a justiça da contribuição de cada um para o custeio da atividade estatal, não representa qualquer novidade ou peculiaridade do sistema tarifário em relação ao que já existia no modelo de prestação direta de serviço. Isso fica bastante evidente quando se considera que a Constituição da República e o Código Tributário Nacional explicitamente preveem que as taxas cobradas pela União, pelos estados, pelo Distrito Federal ou pelos municípios, no âmbito de suas respectivas atribuições, têm como fato gerador a "utilização, efetiva ou potencial", de serviço público específico e divisível, "prestado ao contribuinte ou posto a sua disposição" (art. 77 do CTN e art. 145, II da CF).

Ao ressaltar que a taxa será cobrada pelo serviço público independentemente de sua utilização, o legislador não buscou criar uma fonte de receita indevida para o Estado. Ele simplesmente reconheceu o óbvio: todas as atividades, inclusive os serviços públicos, geram custos variáveis e fixos. Desse modo, sempre que uma pessoa física ou jurídica estiver conectada ao serviço na qualidade de usuário, deverá pagar pelo serviço ainda que não o tenha utilizado efetivamente, ou seja, pagará um valor básico, porque o serviço gerou custos fixos consideráveis.

\section{Tarifação dos serviços de água e de esgoto}

\subsection{Adoção do modelo de remuneração pelo usuário}

A tarefa de identificar o modelo escolhido no Brasil para a remuneração dos serviços divisíveis de água e esgoto se tornou relativamente simples após 2007, ano de edição da Lei no 11.445, a Lei Nacional de Saneamento. Em seu capítulo VI, dedicaram-se inúmeros dispositivos aos aspectos econômicos e sociais dos referidos serviços e neles se determinou de modo expresso a 
adoção prioritária do sistema de remuneração pelo usuário final. Com efeito, o art. 29 explicitamente prescreve que

os serviços públicos de saneamento básico terão a sustentabilidade econômico-financeira assegurada, sempre que possível, mediante remuneração pela cobrança dos serviços: I - de abastecimento de água e esgotamento sanitário: preferencialmente na forma de tarifas e outros preços públicos, que poderão ser estabelecidos para cada um dos serviços ou para ambos conjuntamente [...].

Do dispositivo transcrito se extraem inúmeras conclusões relevantes, a saber: i) a não ser que se mostre impossível, os próprios usuários deverão custear os serviços de água e esgoto em cada localidade; ii) a cobrança deverá se dar preferencialmente na forma de tarifa, submetida a um regime jurídico mais flexível, distinto do aplicável às taxas; e iii) a tarifa poderá ser comum ou única para os dois serviços ou individualizada para cada um deles. Em mais de uma ocasião, essa opção pelo modelo tarifário, em detrimento da taxa, foi reafirmada pelos Tribunais brasileiros, inclusive pelo STJ (EREsp $690609{ }^{10} \mathrm{e}$ REsp 740967/RS ${ }^{11}$ ) e pelo STF (RE 488200/MS ${ }^{12}$ ).

10 TRIBUTÁRIO. EMBARGOS DE DIVERGÊNCIA. CONTRAPRESTAÇÃO COBRADA PELO SERVIÇO PÚBLICO DE ÁGUA E ESGOTO. NATUREZA JURÍDICA DE TARIFA. PRECEDENTES DO STJ E DO STF. 1. Este Tribunal Superior, encampando entendimento sedimentado no Pretório Excelso, firmou posição no sentido de que a contraprestação cobrada por concessionárias de serviço público de água e esgoto detém natureza jurídica de tarifa ou preço público. 2. Definida a natureza jurídica da contraprestação, também definiu-se pela aplicação das normas do Código Civil. 3. A prescrição é vintenária, porque regida pelas normas do Direito Civil. 4.. Embargos de divergência providos. (EREsp 690.609/RS, Rel. Ministra ELIANA CALMON, PRIMEIRA SEÇÃO, julgado em 26/03/2008, DJe 07/04/2008).

11 PROCESSO CIVIL. TRIBUTÁRIO. EXECUÇÃO FISCAL. TARIFA DE ÁGUA E ESGOTO. NATUREZA JURÍDICA DE TARIFA OU PREÇO PÚBLICO. DÍVIDA ATIVA. CRÉDITO NÃO TRIBUTÁRIO. PRESCRIÇÃO DECENAL. CÓDIGO CIVIL. 1. O Colendo STF já decidiu, reiteradamente, que a natureza jurídica da remuneração dos serviços de água e esgoto, prestados por concessionária de serviço público, é de tarifa ou preço público, consubstanciando, assim, contraprestação de caráter não tributário. 2. Consectariamente, malgrado os débitos oriundos do inadimplemento dos serviços de água e esgoto terem sido inscritos como dívida ativa, e exigidos mediante execução fiscal, em observância à Lei de Execuções Fiscais, não se lhes pode aplicar o regime tributário previsto nas disposições do $\mathrm{CTN}$, in casu, os relativos à prescrição/decadência, porquanto estes apenas pertinentes às dívidas tributárias, exatamente por força do conceito de tributo previsto no art. $3^{\circ}$ do CTN. 3. A Execução Fiscal ostenta esse nomen juris posto processo satisfativo, que apresenta peculiaridades em razão das prerrogativas do exequente, assim como é especial a execução contra a Fazenda, não sendo servil apenas para créditos de tributos, porquanto outras obrigações podem vir a compor a "dívida ativa". 4. Recurso Especial provido. (REsp 740.967/RS, Rel. Ministro LUIZ FUX, PRIMEIRA TURMA, julgado em 11/04/2006, DJ 28/04/2006, p. 275)

12 DECISÃO: Os recorrentes insurgem-se contra acórdão do Tribunal de Justiça do Estado do Mato Grosso do Sul segundo o qual a contraprestação correspondente ao fornecimento dos 
A autorização legal para a cobrança da tarifa comum, mencionada no item iii acima, fundamenta-se em última instância na relação de quase equivalência do volume de água consumido ao volume de esgoto produzido. Fala-se de quase equivalência, pois, na prática, o retorno de esgoto se mostra ora levemente menor, ora levemente maior ao da água fornecida por uma série de razões técnicas, como captação de água de chuva e indevido lançamento de água pluvial na rede de esgoto (fatores que tornam o retorno de esgoto maior que o volume de água fornecido) ou utilização de água para atividades como irrigação de plantas, consumo humano etc. (fatores que reduzem o retorno). Justamente por isso, os Tribunais brasileiros já chancelaram essa técnica de cobrança em muitos julgados, não cabendo aqui, porém, maior aprofundamento sobre o tema. ${ }^{13-14}$

serviços de água e esgoto possui caráter tributário. 2. Alega-se, no extraordinário, violação do disposto no artigo 175, inciso III, da Constituição do Brasil. 3. A jurisprudência do Supremo está consolidada no entendimento de que a remuneração pela prestação do serviço de fornecimento de água e coleta de esgoto não tem caráter de tributo, mas de preço público. Veja-se, v.g., o RE no 54.491, Relator o Ministro Hermes Lima, $2^{\text {a }}$ Turma, DJ de 15.10.63. Nesse mesmo sentido: RE no 429.664, Relator o Ministro Cezar Peluso, DJ de 24.3.06; RE no 330.353, Relator o Ministro Carlos Britto, DJ de 10.5.05; AI no 397.797, Relator o Ministro Carlos Velloso, DJ de 6.2.06. 4. Ainda que no caso discuta-se o serviço público compulsório, a remuneração cobrada pela empresa concessionária é contratual, de modo que a sua criação e majoração independem de lei. Notese que a compulsoriedade referida pelo artigo 179, I, "b" do Código Tributário Nacional há de ser e só pode ser, como observou ALIOMAR BALEEIRO. 4. Ainda que no caso discuta-se o serviço público compulsório, a remuneração cobrada pela empresa concessionária é contratual, de modo que a sua criação e majoração independem de lei. Note-se que a compulsoriedade referida pelo artigo 179, I, "b" do Código Tributário Nacional há de ser e só pode ser, como observou ALIOMAR BALEEIRO [Direito tributário brasileiro. 10. ed. Rio de Janeiro: Forense, 1981, p. 353], compulsoriedade de pagamento do tributo [taxa, no caso] e não de uso do serviço. O preceito do Código Tributário Nacional não afirma a impossibilidade da incidência de taxa pela utilização potencial de serviço público facultativo. A recíproca é verdadeira. A concessão do serviço público pressupõe o pagamento, pelo usuário, ao concessionário, de preço público [ = tarifa]. Dou provimento ao recurso extraordinário com fundamento no disposto no artigo 557, §1 $1^{\circ}-\mathrm{A}$, do CPC para reformar o acórdão recorrido, reconhecendo o caráter não tributário da contraprestação de que se cuida, preço público e não taxa. Publiquese. Brasília, 13 de setembro de 2006. Ministro Eros Grau - Relator - 1 (RE 488200, Relator(a): Min. EROS GRAU, julgado em 13/09/2006, publicado em DJ 26/09/2006 PP-00095).

13 PRESTAÇÃO DE SERVIÇOS - FORNECIMENTO DE ÁGUA E COLETA DE ESGOTO DECLARATÓRIA - Alegação da usuária de que a concessionária de serviços públicos exige indevidamente a cobrança de tarifa de coleta de esgoto na mesma proporção do consumo de água, cobrando por serviço não prestado - Procedência da ação em primeiro grau, porém, com redução da tarifa de esgotos a ser estipulada na proporção determinada no laudo pericial, ou seja, em $80 \%$ da água consumida. Afastamento - Tese lançada pelo Colendo Superior Tribunal de Justiça em sede de Recurso Especial Repetitivo sustentando a Legalidade e constitucionalidade da base de cálculo da tarifa do esgoto calculada sobre o consumo de água Preliminar de nulidade processual rejeitada - Discussão sobre a alegação de julgamento extra petita quanto à devolução dos valores, que fica prejudicada ante a resultante da ação Recurso da concessionária ré provido para julgar improcedente a ação declaratória. (TJSP, Apelação Cível n. 0101432-78.2008.8.26.0100).

14 PRESTAÇÃO DE SERVIÇOS. TARIFA DE COLETA DE ESGOTO. AÇÃO ANULATÓRIA DE FATURAS CUMULADA COM OBRIGAÇÃO DE FAZER. PRETENSÃO DE ALTERAÇÃO 
Imprescindível por ora é simplesmente atestar a clara opção do legislador pátrio pelo modelo de remuneração direta pelo usuário no art. 29, I da Lei de Saneamento. Essa opção encontra reforço em inúmeros outros dispositivos do diploma. Ao cuidar da delegação dos serviços por contrato de concessão ou de programa, por exemplo, a lei exige a observância de alguns requisitos, entre os quais a existência de normas de regulação que cuidem das "condições de sustentabilidade e equilíbrio econômico-financeiro da prestação dos serviços, em regime de eficiência, incluindo: a) o sistema de cobrança e a composição de taxas e tarifas; b) a sistemática de reajustes e de revisões de taxas e tarifas; e c) a política de subsídios" (art. 11, §2º, IV).

Em outro trecho, ainda ao tratar dos serviços atribuídos a diferentes prestadores, a lei evidencia a escolha pelo sistema baseado primariamente na cobrança das unidades usuárias ao estipular que a entidade reguladora definirá "as normas econômicas e financeiras relativas às tarifas, aos subsídios e aos pagamentos por serviços prestados aos usuários e entre os diferentes prestadores envolvidos" (art. 12, §1ํㅡㄴ II). A seu turno, dispõe o art. 22, IV, que a regulação terá como objetivo, entre outras coisas, "definir tarifas que assegurem tanto o equilíbrio econômico e financeiro dos contratos como a modicidade tarifária, mediante mecanismos que induzam a eficiência e eficácia dos serviços e que permitam a apropriação social dos ganhos de produtividade". Tanto este quanto os outros dispositivos apontados comprovam, a toda evidência, que o modelo primário de remuneração é o tarifário, cabendo às receitas não tarifárias, como os subsídios, um papel secundário.

\subsection{Regras de estruturação da tarifa de água e esgoto}

Além de explicitar a escolha por um modelo de remuneração, a Lei de Saneamento atribui às agências reguladoras competentes a estruturação das tarifas dos serviços divisíveis que compõem o amplo setor em debate, como revelam os art. 11, §2ํㅡ, 12, $1^{\circ}$ e e 22, IV. No mesmo sentido, o art. 23, IV, dispõe

DA FORMA DE CÁLCULO DAS TARIFAS COBRADAS PELO SERVIÇO DE COLETA DE ESGOTO. ALEGAÇÃO DE QUE A TARIFA SERIA DESPROPORCIONAL AOS SERVIÇOS EFETIVAMENTE PRESTADOS. CONSTITUCIONALIDADE DA COBRANÇA POR SIMPLES AVALIAÇÃO, COM BASE NO VOLUME DE ÁGUA CONSUMIDO. CRITÉRIO ADOTADO POR QUESTÕES DE POLÍTICA TARIFÁRIA. TARIFA JUSTIFICADA PELA MERA COLETA DO ESGOTO, CONFORME DECIDIDO PELO EGRÉGIO SUPERIOR TRIBUNAL DE JUSTIÇA EM RECURSO REPETITIVO (RESP. no⒈339.313/RJ, REL. MINISTRO BENEDITO GONÇALVES.). (TJSP, Apelação 1003171-91.2016.8.26.0161). 
que a entidade reguladora assume a incumbência de definir "requisitos operacionais e de manutenção dos sistemas" e o "regime, estrutura e níveis tarifários, bem como os procedimentos e prazos de sua fixação, reajuste e revisão" (g.n.). Ao conferir a tarefa de estruturação tarifária a um ente autônomo composto por servidores especializados, o legislador não agiu de forma ingênua. Ele buscou, em verdade, evitar táticas populistas, impedir a manipulação tarifária para gerar receitas indevidas ao titular do serviço e obstar decisões tecnicamente frágeis em prejuízo da sustentabilidade do sistema de saneamento.

Reitere-se: os dispositivos legais mencionados demonstram que, no ordenamento brasileiro, somente entidades dotadas de expertise técnica e certa blindagem político-partidária estão autorizadas a executar a tarefa de examinar os diversos elementos de despesa que os serviços de saneamento envolvem, convertendo-os em uma tarifa capaz de assegurar a prestação adequada ao usuário, a remuneração do prestador à luz da equação de equilíbrio econômico-financeiro e, simultaneamente, o funcionamento sustentável do setor em uma perspectiva transgeracional. Ao incumbir exclusivamente o regulador da definição das tarifas, quis o legislador, em última instância, repelir a ingerência de órgãos não especializados nos serviços de saneamento, dadas as óbvias consequências nocivas desse tipo de intervenção.

Isso não significa que as agências do setor possam agir de modo aleatório, não planejado ou abusivo. Em verdade, sua atuação há que ser sempre técnica e observar uma lógica semelhante por todo o território nacional a despeito de ser o serviço de saneamento, primariamente, um serviço de titularidade local. Para garantir a tecnicidade e esse mínimo de homogeneidade diante da pluralidade de entes reguladores, a Lei de Saneamento oferece alguns parâmetros mais detalhados acerca da "estrutura tarifária", ou melhor, aponta diretrizes e elementos a orientar o regulador na fixação do valor da cobrança ao usuário final.

Em primeiro lugar, a estruturação é minudenciada no art. 29, §1ํㅡㄹ da lei, segundo o qual a

instituição das tarifas, preços públicos e taxas para os serviços de saneamento básico observará as seguintes diretrizes: I - prioridade para atendimento das funções essenciais relacionadas à saúde pública; II - ampliação do acesso dos cidadãos e localidade de baixa renda aos serviços; III - geração dos recursos necessários para realização dos investimentos, objetivando o cumprimento das metas e objetivos do 
serviço; IV - inibição do consumo supérfluo e do desperdício de recursos; $\mathrm{V}$ - recuperação dos custos incorridos na prestação do serviço, em regime de eficiência; VI - remuneração adequada do capital investido pelos prestadores dos serviços; VII - estímulo ao uso de tecnologias modernas e eficientes, compatíveis com os níveis exigidos de qualidade, continuidade e segurança na prestação dos serviços; e VIII - incentivo à eficiência dos prestadores dos serviços (g.n.).

Essas diretrizes delimitam, no setor de saneamento, os fatores internos e externos de custos dos serviços e, com isso, delineiam a razão e a destinação dos valores cobrados dos usuários finais. Em consonância com as diretrizes, os valores das tarifas jamais poderiam se resumir ao mero volume de água e de esgoto efetivamente consumidos, nem mesmo aos custos inerentes ao serviço. Elas confirmam o que certa vez escreveu Carlos Ari Sundfeld de modo bastante oportuno. A fixação do preço a ser individualmente pago não é o resultado de uma mera operação aritmética simples. Ele varia em função de muitos critérios. ${ }^{15}$

Como expressa a Lei de Saneamento, há fatores de custos externos diversos e que as tarifas necessitam cobrir, como a atualização das tecnologias empregadas nos serviços, a recuperação de custos de investimento, a garantia de acesso à população de baixa renda (por subsídios tarifários ou não tarifários $)^{16}$ e a remuneração adequada do prestador. Adicionalmente, dois aspectos merecem destaque: i) a tarifa de saneamento poderá desempenhar uma função preventiva, de maneira a ser aumentada sob certas condições com o objetivo de evitar que o usuário consuma o serviço em excesso ou desperdice recursos, sobretudo água, e ii) poderão ser adotados "mecanismos tarifários de contingência", de acordo com o art. 46 da Lei, para cobrir custos adicionais em situações críticas de escassez ou contaminação de recursos hídricos que obriguem a adoção de racionamento.

15 SUNDFELD, Carlos Ari. Pareceres: direito administrativo contratual. São Paulo: Revista dos Tribunais, 2013. v. II, p. 81-82.

16 Art. 31. Os subsídios necessários ao atendimento de usuários e localidades de baixa renda serão, dependendo das características dos beneficiários e da origem dos recursos: I - diretos, quando destinados a usuários determinados, ou indiretos, quando destinados ao prestador dos serviços; II - tarifários, quando integrarem a estrutura tarifária, ou fiscais, quando decorrerem da alocação de recursos orçamentários, inclusive por meio de subvenções; III - internos a cada titular ou entre localidades, nas hipóteses de gestão associada e de prestação regional. 
Em segundo lugar, para além das diretrizes do art. 29, mas em harmonia com elas, a Lei de Saneamento enumera no art. 30 os fatores que poderão ser levados em consideração pelo regulador na sua função de estruturação tarifária, incluindo:

I - categorias de usuários, distribuídas por faixas ou quantidades crescentes de utilização ou de consumo; II - padrões de uso ou de qualidade requeridos; III - quantidade mínima de consumo ou de utilização do serviço, visando à garantia de objetivos sociais, como a preservação da saúde pública, o adequado atendimento dos usuários de menor renda e a proteção do meio ambiente; IV - custo mínimo necessário para disponibilidade do serviço em quantidade e qualidade adequadas; V — ciclos significativos de aumento da demanda dos serviços, em períodos distintos; e VI - capacidade de pagamento dos consumidores (g.n.).

O conjunto de fatores enumerados detém caráter reconhecidamente exemplificativo para a estruturação tarifária a ser executada pelo regulador. Esses fatores, e também outros ali não previstos, serão empregados na medida em que se mostrem necessários ao cumprimento dos planos de saneamento e das diretrizes gerais de tarifação contidas no art. 29. Dada a tecnicidade do assunto, conforme exige a lei em mais de um artigo, caberá unicamente ao regulador o serviço de identificar os fatores determinantes para o alinhamento da tarifa cobrada às finalidades do sistema, devendo fazê-lo sempre de modo claro e objetivo (art. 39 da Lei).

\subsection{Quantidades e tarifas mínimas na legislação setorial}

A oferta de um mínimo de serviços de saneamento à população configura um direito do cidadão e um dever do Estado resultante tanto da Constituição da República (art. 196, caput da CF), quanto de documentos internacionais. Em novembro de 2002, o Comitê da ONU para Direitos Econômicos, Sociais e Culturais aprovou o Comentário Geral no 15, de acordo com o qual: “o direito humano à água prevê que todos tenham água suficiente, segura, aceitável, fisicamente acessível e a preços razoáveis para usos pessoais e domésticos". Quase dez anos mais tarde, em 2011, o Conselho de Direitos Humanos da ONU editou a Resolução 16/2, mais uma vez a reforçar o direito ao saneamento e, 
por conseguinte, à água como um direito à vida e à dignidade. A OMS, a seu turno, afirma serem "necessários entre 50 a 100 litros de água por pessoa, por dia, para assegurar a satisfação das necessidades mais básicas e a minimização dos problemas de saúde". ${ }^{17}$

Esses documentos internacionais demandam que os sistemas e as redes de saneamento básico, sobretudo de fornecimento de água e coleta de esgoto, estejam permanentemente preparados a oferecer o mínimo essencial, assim que um indivíduo dele necessitar. E isso implica ao Estado tomar as providências necessárias para manter a rede em constante funcionamento a despeito de uma ou outra variação de demanda, de sorte a garantir a capacidade de atendimento exigida. Para tanto, deverá consequentemente recolher os valores necessários a custear o bom estado da infraestrutura, garantindo a sustentabilidade do sistema.

É a partir dessa lógica que se deve interpretar o art. 30, incisos III e IV, da Lei de Saneamento. Como dito, o artigo em questão enumera fatores a serem levados em conta na estruturação da tarifa, incluindo a observância de "quantidade mínima de consumo ou de utilização do serviço, visando à garantia de objetivos sociais, como a preservação da saúde pública [...]" (inciso III) e o "custo mínimo necessário para disponibilidade do serviço em quantidade e qualidade adequadas" (inciso IV, g.n.).

Esses dois incisos estão umbilicalmente relacionados. Na medida em que o Estado tem o dever de garantir uma quantidade mínima do serviço na qualidade adequada sempre que o cidadão dele necessitar (inciso III), dispõe ele do poder-dever de calcular e cobrar o custo mínimo para que a rede esteja pronta a responder à demanda potencial. Pelo outro lado da moeda, ou melhor, da perspectiva do consumo, ao mesmo tempo que se garante ao cidadão um direito ao serviço em quantidade e qualidade adequadas, recai sobre ele o dever de custear o serviço para que sua infraestrutura preserve a capacidade de atendimento nos padrões desejados. Em poucas palavras, na tarefa de construir e manter um sistema de saneamento preparado a garantir dignidade a todos e a proteção do ambiente, prestador e usuários têm deveres e direitos inter-relacionados. Ao regulador, nesse contexto, compete manter o equilíbrio entre esses deveres e estimular a satisfação dos direitos envolvidos.

17 ONU. O direito humano à água e saneamento. Disponível em: <www.un.org/waterforlifedecade/ pdf/human_right_to_water_and_sanitation_media_brief_por.pdf $>$. 
Ressalte-se: o acesso e a disponibilidade mínima dos serviços de água e de esgoto decorrem de uma necessidade humana reconhecida no contexto interno e pela comunidade internacional, daí por que não pode o cidadão se recusar a colaborar, dentro do modelo de remuneração escolhido pelo legislador brasileiro, com a estruturação e manutenção da infraestrutura necessária a viabilizá-los, ou seja, com custos de capital e de operação que o sistema gera. A fixação e cobrança de uma tarifa básica capaz de arcar com os custos fixos mínimos dos serviços de saneamento, sobretudo os de disponibilização e de manutenção de uma rede em condições de operação conforme a quantidade e qualidade desejadas, não é uma escolha, senão um dever dos atores envolvidos no sistema.

Exatamente por isso, na medida em que o art. 45, caput da Lei de Saneamento determina que, salvo disposição contrária do titular, do regulador ou da legislação ambiental, "toda edificação permanente urbana será conectada às redes públicas de abastecimento de água e de esgotamento sanitário disponíveis", é natural que os proprietários dessas edificações se sujeitem automaticamente "ao pagamento das tarifas e de outros preços públicos decorrentes da conexão e do uso desses serviços". Observe-se com atenção a parte final do art. 45! O dispositivo se refere de modo muito claro tanto ao preço público de "uso desses serviços" quanto ao de "conexão", ou seja, aos valores resultantes do simples fato de a rede permanecer disponível e preparada a oferecer ao usuário a oferta do serviço na quantidade e na qualidade mínimas exigidas.

Sinteticamente, portanto, a tarifa mínima, reconhecida na legislação setorial de modo inquestionável (art. 30, IV, e art. 45) necessita ser compreendida diante da função social dos serviços de saneamento e da complexidade de sua disponibilização e de seu funcionamento tanto em termos econômicos quanto técnicos - aspectos cuja análise cabe, por lei, somente a órgãos regulatórios especializados. Vale aqui o alerta geral de Sundfeld. É preciso respeitar o sistema de cobrança instituído para o atendimento de uma política pública com suas justificativas econômicas ou sociais. ${ }^{18}$ Sem isso, corre-se o risco de se inviabilizar a prestação adequada do serviço, sacrificando-se interesses públicos e, não raro, os próprios usuários finais.

18 Carlos Ari Sundfeld, Pareceres, op. cit., p. 82. 


\section{Tarifação e normas de defesa do usuário (CDC e CDUSP)}

\subsection{Prevalência da norma regulatória diante do CDC}

Para conferir segurança jurídica aos atores envolvidos na regulação e na prestação de serviços públicos, especialmente os de distribuição de água e de coleta de esgoto, é imprescindível verificar se a cobrança de tarifas mínimas, bem como a definição de métodos de cálculo específicos pelos reguladores com base em diretrizes da legislação setorial se chocam com o Código de Defesa do Consumidor e outras leis básicas de defesa dos usuários. Em outras palavras: as normas gerais do CDC e do recém-editado CDUSP são capazes de afastar normas especiais de regulação setorial em matéria tarifária ou, diversamente, as decisões regulatórias repelem a incidência das normas básicas de proteção do usuário?

A indagação é inevitável, em especial porque o CDC abarca inúmeras normas que se referem de modo direto ou indireto aos serviços públicos. A título de exemplo, seu art. 39 dispõe ser "vedado ao fornecedor de produtos ou serviços, entre outras práticas abusivas: I - condicionar o fornecimento de produto ou de serviço ao fornecimento de outro produto ou serviço, bem como, sem justa causa, a limites quantitativos" (g.n.) e "VIII - colocar, no mercado de consumo, qualquer produto ou serviço em desacordo com as normas expedidas pelos órgãos oficiais competentes ou, se normas específicas não existirem, pela Associação Brasileira de Normas Técnicas ou outra entidade credenciada pelo Conselho Nacional de Metrologia, Normalização e Qualidade Industrial (Conmetro)".

Os dois dispositivos citados a título de ilustração são capazes de afetar, sobretudo por interpretações descuidadas ou apressadas, a instituição de tarifas básicas de serviços públicos e igualmente a autonomia das agências reguladoras para instituição de normas técnicas, como as relativas à estruturação tarifária. Daí advém a necessidade de se superar a indagação inicial, esclarecendo-se os motivos pelos quais normas básicas de defesa do usuário se tornam inaplicáveis diante de normatizações setoriais sobre um mesmo assunto.

A fim de se justificar essa conclusão, basta uma análise formal. Dessa perspectiva, cumpre verificar se, de modo geral, o CDC rege serviços públicos e sob quais condições. Ao fazê-lo, dois momentos históricos necessitam ser diferenciados: o de 1990 a 2017, ou seja, o período que se inicia com a edição do CDC e prossegue até a edição do Código de Defesa do Usuário de Serviços 
Públicos (Lei no 13.460/2017, doravante CDUSP) e o momento atual, no qual ambos os Códigos convivem.

Tomando-se em conta o cenário anterior à edição do CDUSP, a doutrina brasileira tendia a aceitar a convivência das normas privatistas com as normas administrativas e regulatórias regentes dos serviços públicos. Numa perspectiva comparada, Alexandre Santos de Aragão identificou três teorias a respeito do assunto: a publicista, a privatista e a mista, ${ }^{19}$ que, a seu ver, seria a mais compatível com o ordenamento jurídico brasileiro, mormente em face das disposições dos art. 7ํ, caput, da Lei $\mathrm{n}^{-0} 8.987 / 1995,{ }^{20}$ e dos arts. $6^{\circ}$, X, e 22 do CDC. ${ }^{21}$

Segundo Aragão, à luz da teoria mista, é inaceitável o tratamento estritamente privatista dos usuários dos serviços públicos, já que eles sofrem um forte influxo de normas de direito público. É verdade que o usuário se encontra unido à prestadora do serviço por um contrato. Contudo, o interesse público a ser satisfeito através do serviço público justifica que o Estado estabeleça o seu regime jurídico. ${ }^{22}$ Em outras palavras, de acordo com o modelo misto ou híbrido, os serviços públicos se subordinam primariamente a normas de direito administrativo, a que se somam apenas subsidiariamente as normas do direito privado, sobretudo do direito do consumidor, tal como evidencia a Lei de Concessões e o CDC nos dispositivos mencionados no parágrafo anterior.

No modelo misto, ressalte-se, prevalecem as normas públicas. E isso também explica Aragão. Os serviços públicos têm uma conotação coletiva muito mais ampla do que as atividades econômicas privadas, já que visam à coesão social e, inclusive, são utilizados muitas vezes como instrumento técnico de distribuição de renda e realização da dignidade da pessoa humana, ${ }^{23}$

19 ARAGÃO, Alexandre Santos de. Serviços públicos e direito do consumidor: possibilidades e limites da aplicação do CDC. Revista Eletrônica de Direito Administrativo Econômico, n. 15, p. 1, 2008.

20 Art. $7^{\circ}$. Sem prejuízo do disposto na Lei $n^{\circ}$ 8.078, de 11 de setembro de 1990, são direitos e obrigações dos usuários [...].

${ }^{21}$ Art. $6^{\circ}$ São direitos básicos do consumidor: [...]X - a adequada e eficaz prestação dos serviços públicos em geral.

Art. 22. Os órgãos públicos, por si ou suas empresas, concessionárias, permissionárias ou sob qualquer outra forma de empreendimento, são obrigados a fornecer serviços adequados, eficientes, seguros e, quanto aos essenciais, contínuos.

Parágrafo único. Nos casos de descumprimento, total ou parcial, das obrigações referidas neste artigo, serão as pessoas jurídicas compelidas a cumpri-las e a reparar os danos causados, na forma prevista neste código.

22 Alexandre Santos de Aragão, Serviços públicos e direito do consumidor, op. cit., p. 13.

23 Ibid., p. 17. 
por exemplo com o financiamento da expansão aos que ainda não têm acesso ao serviço por usuários já conectados. Floriano de Azevedo Marques Neto segue a mesma linha de raciocínio ao ressaltar a necessidade de se considerar as peculiaridades dos serviços públicos quando da aplicação das normas de proteção do consumidor. ${ }^{24}$ Opinião semelhante é a de Carlos Ari Sundfeld, para quem as normas gerais de proteção do consumidor constituem um arcabouço básico. ${ }^{25}$

Sundfeld explica, nessa linha, que o próprio CDC reconhece a competência das autoridades administrativas para definir a política tarifária. ${ }^{26}$ Além disso, quando o Código de Defesa do Consumidor trata das condutas abusivas, menciona hipóteses genéricas referentes ao aumento injustificado de preços e à exigência de vantagens excessivas dos consumidores (art. 39, V e X), a abusividade deverá ser medida pela desobediência às regras de regulação setorial. ${ }^{27}$ Em outras palavras, as normas consumeristas sempre cedem diante dos parâmetros de cobrança estabelecidos pelos órgãos estatais responsáveis por análises técnico-regulatórias.

Em 2017, com a edição da Lei nº 13.460, já conhecida como Código de Defesa do Usuário de Serviços Públicos, a relação do arcabouço de direito público com as normas privadas de proteção dos consumidores passou a ser objeto de regras de interação mais claras, porém não menos complexas. Apesar de algumas mudanças, a edição do novo Código deixou intocados dois aspectos fundamentais: i) a adoção do referido sistema misto no Brasil e ii) a primazia do sistema regulatório sobre as normas gerais de proteção dos usuários.

Em consonância com posicionamento já defendido em estudo sobre o assunto, ${ }^{28}$ os mandamentos protetivos do CDUSP valem para todos os entes da administração direta e indireta em qualquer um dos três níveis federativos (União, estados e municípios). A cada um desses níveis compete a tarefa de minudenciar as normas gerais de proteção em diplomas próprios.

24 MARQUES NETO, Floriano de Azevedo. A nova regulação dos serviços públicos. Revista de Direito Administrativo, v. 228, p. 28-29, 2002.

25 Carlos Ari Sundfeld, Pareceres, op. cit., p. 83.

26 Ibid., p. 86.

27 Ibid.

28 MARRARA, Thiago. O Código de Defesa de Usuários de Serviços Públicos. Colunistas Direito do Estado, n. 383. Disponível em: <www.direitodoestado.com.br/colunistas/thiago-marrara/ocodigo-de-defesa-do-usuario-de-servicos-publicos-lei-n-13460-2017-seis-parametros-deaplicabilidade>. 
No entanto, conforme disposição expressa (art. 1은 §ºa), a aplicação das normas do Código não deve servir de argumento para afastar o cumprimento de "normas regulamentadoras específicas", nem de normas previstas no CDC quando efetivamente caracterizada uma relação de consumo.

Como se vislumbra, a edição do CDUSP em 2017 não altera a prevalência das normas regulatórias. Em verdade, a novidade trazida pelo Código consiste única e exclusivamente na modificação da ordem de aplicação do conjunto de normas básicas de proteção do usuário. Afinal, como tanto o CDUSP quanto o CDC configuram corpos de normas nacionais e básicas, tornou-se imprescindível esclarecer qual deles incidirá no caso concreto de modo primário e qual se aplicará apenas de maneira subsidiária.

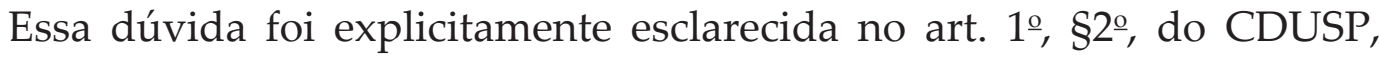
acima transcrito. Em casos de prestação do serviço público pela Administração Direta ou Indireta, o Código dos Usuários incidirá como o conjunto de normas básicas primárias, aplicando-se as garantias do CDC somente em sentido subsidiário ou residual. Já no âmbito dos serviços públicos prestados por particulares na qualidade de delegatários (execução indireta), a ordem de aplicabilidade se inverterá: o CDC passará ao papel de diploma primário e o CDUSP incidirá de maneira subsidiária (art. 1ํㅗㅇำ $3^{\circ}$.

Diante da pluralidade de diplomas básicos de proteção do consumidor e do usuário com validade em todo o território nacional, o CDUSP oportunamente definiu o corpo básico de normas protetivas que incidirá em um ou outro caso concreto conforme um critério que valoriza o tipo de prestador e, ao fazê-lo, inseriu um novo critério para a discussão da relação do CDC com os serviços públicos no Brasil (o critério subjetivo). Apesar disso, como já dito, nada mudou quanto à adoção do modelo misto na composição do regime jurídico, pois, a despeito do prestador, o direito público se somará ao direito privado sempre que houver relação de consumo.

Ademais, e o que é mais importante para o presente estudo, restou intocada pelo CDUSP a primazia da regulação setorial. Isso se observa quando o novo Código: i) reconhece que suas normas de proteção, bem como as normas do CDC, configuram normas "básicas" e ii) expressamente prescreve que suas normas não afastam a necessidade de observância de "normas regulamentadoras específicas, quando se tratar de serviço ou atividade sujeitos à regulação e à supervisão" (art. 1ํㅡㅇ §2으. I, do CDUSP). Em outras palavras, se existir, para um determinado serviço público, entidade reguladora competente e atuante, suas normas prevalecerão sobre as existentes nos dois Códigos mencionados. Ao se verificar, por exemplo, a atuação de uma agência 
reguladora local ou regional sobre serviços públicos de água ou esgoto com base na lei setorial, as normas do CDC e do CDUSP restarão automaticamente afastadas quanto a assuntos já disciplinados no âmbito regulatório. As normas incidirão somente para assuntos não disciplinados pelo regulador.

Essa conclusão, consagrada no CDUSP, compatibiliza-se em termos teleológicos com o modelo de regulação adotado no Brasil e que, no setor de saneamento, é tido como obrigatório. Além disso, o modelo adotado pelo Código do Usuário obedece à regra clássica da prevalência da norma especial sobre a norma geral ("lex specialis derogat legi generali"), técnica de superação de antinomias consagrada no direito e cujo fundamento é relativamente simples. A norma especial carrega as preocupações e os anseios do legislador sobre um contexto determinado, baseia-se num conhecimento mais aprofundado e verticalizado, daí por que se revela mais aderente às peculiaridades do objeto normatizado.

Note-se que o próprio CDC reconhece de modo explícito a prevalência da norma especial em inúmeros momentos e, indo além, evidencia que, na disputa entre normas igualmente técnicas, sempre prevalecerão as editadas pelo próprio Estado. Isso se observa no art. 39, VIII, de acordo com o qual os produtos e serviços devem estar de acordo com "as normas expedidas pelos órgãos oficiais competentes ou, se normas específicas não existirem, pela Associação Brasileira de Normas Técnicas ou outra entidade credenciada pelo Conselho Nacional de Metrologia, Normalização e Qualidade Industrial (Conmetro)". Nesse dispositivo, entre outros que aqui poderiam ser citados, o legislador afirma de modo incontestável a preferência pelas normas especiais "expedidas pelos órgãos oficiais competentes". Assim, somente na ausência de normas especiais criadas por órgãos públicos dotados de expertise técnica, como os das agências reguladoras de saneamento, incidirá a norma básica do CDC que, a seu turno, remete a especificações não oficiais, como as formuladas pela ABNT (entidade privada sem fins lucrativos cujas normas por si só não são capazes de gerar efetivo extroverso vinculante).

De igual forma e pela mesma lógica, no plano da tarifação, as normas especiais editadas por agências reguladoras prevalecem sobre normas genéricas de tutela do consumidor e do usuário. Ressalte-se: essa conclusão resulta tanto da regra da especialidade quanto do reconhecimento explícito, no CDUSP, do caráter subsidiário do CDC. Ademais, no âmbito dos serviços públicos de saneamento básico, como abastecimento de água e coleta de esgoto, referida conclusão é ainda fortalecida pela inquestionável prevalência da norma posterior sobre a norma anterior. As diretrizes e regras de 
estruturação tarifária da Lei de Saneamento não são apenas especiais em relação às do CDC. Elas são igualmente mais novas ou posteriores, já que o Código do Consumidor é de 1990 e a legislação setorial, de 2007.

\subsection{CDC: aceitação de tarifa mínima por justa causa}

Ad argumentandum tantum, a conclusão quanto à aceitabilidade da tarifa mínima não se alteraria ainda que a teoria do direito ocidental não consagrasse a prevalência da norma especial posterior sobre a norma genérica anterior, e ainda que o recente CDUSP não tivesse claramente explicitado que as normas setoriais demandam observância em qualquer caso. E isso por conta de um aspecto de direito material, ou seja, por uma norma expressamente contida no corpo do CDC e já transcrita anteriormente.

Diz o art. 39, inciso I, do diploma de proteção do consumidor ser vedado ao fornecedor do serviço, entre outras práticas abusivas, "condicionar o fornecimento de produto ou de serviço ao fornecimento de outro produto ou serviço, bem como, sem justa causa, a limites quantitativos" (g.n.). Isso significa, ao avesso, que a fixação de limites quantitativos é aceitável quando houver uma razão justa para tanto. Não há, pois, uma vedação absoluta e definitiva no Código para cobrança de tarifas mínimas, de que são espécies as chamadas tarifas operacionais básicas. A cobrança é possível desde que haja alguma justificativa aceitável para tanto.

Essa justificativa, como visto anteriormente, existe de modo inquestionável no âmbito dos serviços de fornecimento de água e coleta de esgoto. Na medida em que eles se mostram imprescindíveis ao exercício de direitos fundamentais, como à vida e à saúde, interna e internacionalmente se reconhece a necessidade de se garantir um mínimo de prestação ao indivíduo assim que ele necessitar do serviço. Como já dito e repetido, o Estado detém o dever de manter uma rede em bom funcionamento com uma capacidade de atendimento de acordo com a quantidade e qualidade adequadas e, por consequência, dispõe do poder de cobrar do usuário final os valores necessários para tanto.

Ressalte-se: a despeito de qualquer discussão sobre a especialidade ou a posterioridade das normas setoriais diante das normas genéricas de defesa do consumidor ou do usuário, fato é que a cobrança de uma tarifa mínima de água e esgoto detém no mínimo duas causas justas e inter-relacionadas, quais sejam: i) o dever de se garantir um serviço adequado em termos quantitativos 
e qualitativos sempre que a unidade usuária necessitar e ii) a dependência desse dever em relação à cobertura de custos fixos que os serviços geram, sobretudo em termos de manutenção da infraestrutura, a despeito de variações de demanda de curto prazo pelas unidades conectadas à rede existente.

Desse modo, conquanto alguns desejem a todo custo afirmar que o CDC incide integralmente mesmo na presença de normas setoriais - vale repetir, de modo esdrúxulo e ao arrepio da teoria jurídica e da análise sistemática da legislação brasileira - , a tarifa mínima permanecerá lícita, pois há duas causas justas que a sustentam, configurando-se as condições da válvula de escape do art. 39, I, do referido Código. A esse respeito, como se verá, não é outra a conclusão da jurisprudência brasileira.

\subsection{Legalidade da tarifa mínima na jurisprudência}

Os Tribunais brasileiros, sobretudo o Superior Tribunal de Justiça, também corroboram o quanto exposto neste estudo a partir das análises da teoria dos serviços públicos, do regime jurídico de remuneração, da legislação setorial e das normas gerais contidas no CDC e no CDUSP. Em inúmeros julgados, o STJ reafirma não somente a possibilidade de cobrança de tarifa mínima no setor de saneamento, como esclarece que a cobrança da tarifa não pressupõe que já se tenha sido estruturado o sistema por completo. É o que revelam os julgados a seguir:

ADMINISTRATIVO. SERVIÇO DE ESGOTAMENTO SANITÁRIO. PRESTAÇÃO DE ALGUMAS ETAPAS. COLETA E ESCOAMENTO DE DEJETOS. TARIFA DE ÁGUA E ESGOTO. LEGALIDADE DA COBRANÇA. 1. No julgamento do REsp 1.339.313/RJ, submetido à sistemática do art. 543-C do CPC, o STJ firmou o entendimento de que se afigura legal a cobrança de tarifa de esgoto, ainda quando detectada a ausência ou deficiência do tratamento dos resíduos coletados, se outros serviços, caracterizados como de esgotamento sanitário, forem disponibilizados aos consumidores. 2. Ressalta-se que, mesmo antes da vigência da Lei 11.445/2007, havia posicionamento desta Corte no sentido de que "a lei não exige que a tarifa só seja cobrada quando todo o mecanismo do tratamento do esgoto esteja concluído", e "o início da coleta dos resíduos caracteriza prestação de serviço remunerado" (REsp 431.121/SP, Rel. Ministro José Delgado, Primeira Turma, DJ 7/10/2002). 
3. Agravo Regimental não provido.

(STJ - AgRg no REsp: 1505228 PR 2014/0059453-0. Relator: Ministro Herman Benjamin. Data de julgamento: 07/05/2015. T2 - Segunda Turma. Data de publicação: 05/08/2015).

ADMINISTRATIVO. CONCESSIONÁRIA DE SERVIÇO PÚBLICO. TARIFA DE ÁGUA. COBRANÇA COM BASE EM CONSUMO MÍNIMO MENSAL. LEGALIDADE. I - É lícita a cobrança de tarifa de água, em valor correspondente ao consumo mínimo presumido mensal, mesmo que o hidrômetro registre volume menor do que o cobrado, de modo a possibilitar a sustentabilidade do sistema. (Precedentes: EDREsp no 95.920/SC, Relator Ministro GARCIA VIEIRA, DJ de 14/09/1998, p. 9; REsp no 533.607/RJ, Relator Ministro JOSÉ DELGADO, DJ de 28/10/2003, p. 220; REsp nº 20.741/DF, Rel. Min. ARI PARGENDLER, DJ de 03/06/1996, p. 19230). II - O agravante deixou de infirmar os fundamentos da decisão agravada e se limitou a pedir o julgamento do feito pelo colegiado. Aplica-se, pois, a Súmula no 182 desta Corte, segundo a qual "é inviável o agravo do art. 545 do CPC que deixa de atacar especificamente os fundamentos da decisão agravada". III - Agravo regimental improvido.

(AgRg no REsp 843.970/RJ, Rel. Ministro FRANCISCO FALCÃO, PRIMEIRA TURMA, julgado em 19/09/2006, DJ 16/10/2006)

PROCESSO CIVIL E ADMINISTRATIVO. AGRAVO REGIMENTAL. FORNECIMENTO DE ÁGUA E DE ESGOTO. TARIFA MÍNIMA. LEGALIDADE. I - Versa a demanda sobre a cobrança da tarifa mínima de fornecimento de água e de esgoto e não sobre a legalidade da cobrança do valor estimado. II - Esta Corte entende legítima a cobrança da tarifa mínima quando o consumo não atinge o patamar relativo a essa importância. III - Precedentes: REsp no 648248/PB, Rel. Ministro TEORI ALBINO ZAVASCKI, DJ de 19.12.2005; EDcl nos EDcl no REsp no 533607/RJ, Rel. Ministro JOSÉ DELGADO, DJ de 05.08.2004; AgRg no REsp no 140230/MG, Rel. Ministro Francisco Falcão, DJ de 21.10.2002. IV - Agravo regimental improvido.

(AgRg no REsp 858.908/RJ, Rel. Ministro FRANCISCO FALCÃO, PRIMEIRA TURMA, julgado em 19/09/2006, DJ 16/10/2006) 
ADMINISTRATIVO. SERVIÇO PÚBLICO. TAXA DE ÁGUA. COBRANÇA DE TARIFA PELO CONSUMO MÍNIMO. LEGALIDADE. PRECEDENTES JURISPRUDENCIAIS. É lícita a cobrança da taxa de água pela tarifa mínima, mesmo que haja hidrômetro que registre consumo inferior àquele. Inteligência das disposições legais que regulam a fixação tarifária (artigo $4^{\circ}$, da Lei 6.528/78 e artigos 11, caput, $11, \S 2$ e e 32 do Decreto no 82.587/78).

(REsp 416383/RJ; Relator: Ministro LUIZ FUX; PRIMEIRA TURMA; Data do Julgamento: 27/08/2002)

ADMINISTRATIVO. PREÇO PÚBLICO. DISTRIBUIÇÃO DE ÁGUA. TARIFA MÍNIMA. O preço público tem natureza diversa do preço privado, podendo servir para a implementação de políticas governamentais no âmbito social. Nesse regime, a tarifa mínima, a um tempo, favorece os usuários mais pobres, que podem consumir expressivo volume de água a preços menores, e garante a viabilidade econômico-financeira do sistema, pelo ingresso indiscriminado dessa receita prefixada, independentemente de o consumo ter, ou não, atingido o limite autorizado.

(REsp 20.471-DF, Rel. Min. ARI PARGENDLER; Data do Julgamento: 09/05/1996).

Além disso, em mais de uma ocasião, o STJ teve a oportunidade de debater a dúvida a respeito da compatibilidade da cobrança de tarifa mínima com a disposição constante no art. 39, I, do CDC. Ao fazê-lo, reconheceu inexistir qualquer incompatibilidade entre a referida técnica de estruturação das cobranças e o dispositivo genérico do Código, exatamente porque sua vedação não é absoluta, na medida em que aceita exceções por justa causa. Isso se verifica nos seguintes julgados:

ADMINISTRATIVO. SERVIÇO PÚBLICO. TAXA DE ÁGUA. COBRANÇA DE TARIFA. PROGRESSIVIDADE. LEGALIDADE. PRECEDENTES JURISPRUDENCIAIS. 1. É lícita a cobrança da taxa de água com base no valor correspondente a faixas de consumo, nos termos da legislação específica. 2. Inteligência das disposições legais que regulam a fixação tarifária (artigo $4^{\circ}$, da Lei 6.528/78 e artigos 11, caput, 11, §2º e 32 do Decreto nํ 82.587/78). 3. A Lei 8.987/95 autoriza a cobrança do serviço de fornecimento de água de maneira escalonada (tarifa progressiva), 
de acordo com o consumo (art. 13), e não colide com o disposto no art. 39, I, do CDC, cuja vedação não tem caráter absoluto. Precedente: EDcl no REsp 625221/RJ, DJ 25.05.2006. 4. Agravo Regimental desprovido.

(AgRg no REsp 815.373/RJ, Rel. Ministro LUIZ FUX, PRIMEIRA TURMA, julgado em 16/08/2007, DJ 24/09/2007, p. 255)

ADMINISTRATIVO. SERVIÇO PÚBLICO. TAXA DE ÁGUA. COBRANÇA DE TARIFA. PROGRESSIVIDADE. LEGALIDADE. PRECEDENTES JURISPRUDENCIAIS. 1. É lícita a cobrança da taxa de água com base no valor correspondente a faixas de consumo, nos termos da legislação específica. 2. Inteligência das disposições legais que regulam

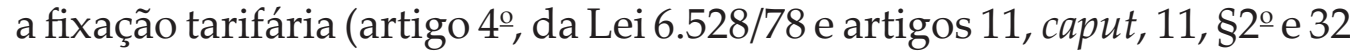
do Decreto no $82.587 / 78)$. 3. A Lei 8.987/95 autoriza a cobrança do serviço de fornecimento de água de maneira escalonada (tarifa progressiva), de acordo com o consumo (art. 13), e não colide com o disposto no art. 39, I, do $C D C$, cuja vedação não tem caráter absoluto. Precedente: EDcl no REsp 625221/RJ, DJ 25.05.2006. 4. Agravo Regimental desprovido.

(AgRg no REsp 815.373/RJ, Rel. Ministro LUIZ FUX, PRIMEIRA TURMA, julgado em 16/08/2007, DJ 24/09/2007, p. 255)

\section{Conclusões}

1 - Com base na legislação de saneamento brasileira e nos preceitos de direito administrativo é lícito instituir a cobrança de tarifa mínima (ou criação de uma tarifa básica operacional - TBO) para manutenção dos serviços de água e esgoto?

A cobrança de tarifa mínima para a manutenção de serviços públicos de fornecimento de água e de coleta de esgoto é lícita e compatível tanto com a legislação setorial quanto com a legislação de defesa dos usuários de serviços públicos e de defesa do consumidor. A tarifa mínima está intimamente relacionada ao cumprimento do dever - reconhecido no ordenamento brasileiro e reforçado pelas organizações internacionais, como a ONU e a OMS de se estruturar e se manter uma rede de prestação de serviços de água e de esgoto capaz de atender, com a qualidade e a quantidade adequadas, a demanda de todas as unidades conectadas. Nesse contexto, ao direito de obter o serviço adequado no momento desejado corresponde, para o usuário, 
o dever de contribuir para a cobertura dos custos internos e externos do serviço, incluindo não somente os custos variáveis (que flutuam ao sabor da demanda), como os fixos (que se mantêm invariáveis no curto prazo). Isso se extrai da Lei de Saneamento (art. 29 e art. 30, incisos III e IV), que expressamente estabelece diretrizes e regras detalhadas de estruturação tarifária do setor e requer do regulador competente pela tarefa de fixação da tarifa a consideração da disponibilidade mínima de serviço e dos custos daí derivados. Além de econômica e socialmente racional, pois imprescindível a garantir o bom funcionamento da infraestrutura de um sistema essencial à vida de todos, referida metodologia de cálculo encontra amparo em farta jurisprudência do STJ, que, em incontáveis oportunidades, reafirmou a legalidade da tarifa mínima no setor de saneamento.

2 - As tarifas dos serviços de água e esgoto estão vinculadas à legislação consumerista, devendo cobrar do usuário somente o serviço efetivamente usufruído ou tal preceito do Código de Defesa do Consumidor pode ser afastado?

O art. 39, I do Código de Defesa do Consumidor de 1990 (CDC) considera abusivo condicionar o fornecimento de serviço a limites quantitativos sem justa causa. No entanto, nem o CDC, nem o Código de Defesa do Usuário de Serviços Públicos (Lei no 13.460 de 2017 - CDUSP) obstam a cobrança de tarifa mínima para serviços de água e de esgoto, estruturada em linha com as previsões da Lei Nacional de Saneamento. Em primeiro lugar, as normas da legislação de saneamento são posteriores e especiais, sobrepondo-se às normas genéricas e anteriores do CDC, inclusive à contida em seu art. 39, inciso I ("lex specialis derogat legi generali" e "lex posteriori derogat legi priori"). Em segundo lugar, o CDUSP, recentemente editado, prescreve a observância de normas regulatórias independentemente das normas básicas (art. 1으, §2은 I). Melhor dizendo: o novo diploma revela que normas dos setores regulados, por sua especialidade, continuam a ter preferência. Por conseguinte, se o prestador for público, sobre ele incidirão primariamente as normativas regulatórias, seguidas das disposições do CDUSP e, de maneira residual, das do CDC. Ao contrário, se o prestador for privado, novamente as normativas regulatórias incidirão de modo primário, mas seguidas das disposições do CDC e, somente em último plano, das contidas no CDUSP. Em terceiro lugar, ad argumentandum tantum, mesmo que se ignorasse por completo a prevalência da norma especial e posterior, a tarifa mínima para serviços de saneamento permaneceria lícita à luz do CDC, uma vez que o art. 39, I, a autoriza contanto que se comprove uma "justa causa". E não há dúvidas de 
que muitos motivos existem a justificá-la no setor de saneamento. De um lado, os valores mínimos cobrados do usuário, a despeito de variações efetivas de consumo, baseiam-se no dever de o prestador organizar e manter uma infraestrutura capaz de suportar a demanda mínima de todas as unidades conectadas às redes de água e de esgoto a qualquer momento. De outro, essa capacidade de resposta, ou seja, de atendimento eficaz ao usuário tanto em termos qualitativos quanto quantitativos depende da cobertura não só de custos variáveis, senão igualmente de custos fixos incontáveis e de diversas ordens, ou seja, de custos que permanecem invariáveis no curto prazo, a despeito de um ou outro usuário não se valer da prestação. Em conclusão, mesmo diante de uma interpretação isolada do art. 39, I, do CDC - o que, vale dizer, não se harmoniza com a prevalência dos diplomas setoriais -, a tarifa mínima de água e esgoto permanece lícita, pois inquestionavelmente lastreada em justa causa.

Thiago Marrara

Professor associado de direito administrativo

FDRP/USP 